\title{
Parents as first Teachers for Children
}

\author{
Rosalia Windu Asih \\ Universitas Sebelas Maret \\ rossawindu@gmail.com
}

\section{Article History}

accepted 14/11/2020

\begin{abstract}
Parents are the firs environment a child experiences when he is born into the world.Furthermore, parents are also the main environment in shaping a child's personality. At the beginning of their growth, they tend to spend more with the family environment,especially parents. Then in the family a child experiences the first and foremost educational process of the parents. All forms of parental behaviour,both oral and good deeds that are exemplary and habits applied in social life wiil affect the pattern of child development. Therefore,my parents should able to instill a good education and of course this is true in children from an early age,so that the subsequent development of children can reflect a good and noble personality as well as be beneficial for themselves , parentsriligion, society and nation and country.
\end{abstract}

Keywords: parents, education

\begin{abstract}
Abstrak
Orang tua merupakan lingkungan pertama yang dialami seorang anak ketika dilahirkan ke dunia. Selanjutnya orang tua juga merupakan lingkungan utama dalam pembentukan kepribadian seorang anak. Pada awal pertumbuhannya cenderung lebih banyak dihabiskan bersama lingkungan keluarga terutama orang tua.Maka dalam keluarga seorang anak mengalami proses pendidikan yang pertama dan utama dari orang tua.Segala bentuk perilaku orang tua baik lisan maupun perbuatan baik yang bersifat keteladanan maupun kebiasaan yang diterpakan dalam kehidupan sosial akan mempengaruhi pola perkembangan anak .Oleh sebab itu orang tua seyogyanya mampu menanamkan pendidikan yang baik dan tentunya benar pada anak sejak usia dini, agar perkembangan anak selanjutnya dapat mencerminkan kepribadian yang baik dan luhur serta bermanfaat bagi dirinya sendiri ,orang tua ,agama, masyarakat serta bangsa dan negaranya.
\end{abstract}

Kata kunci: Orang tua, pendidikan

Social, Humanities, and Education Studies (SHEs): Conference Series https://jurnal.uns.ac.id/shes

p-ISSN 2620-9284

e-ISSN 2620-9292 


\section{PENDAHULUAN}

Dalam proses pendidikan diperlukan satu penegasan secara khusus untuk menghasilkan sesuatu yang sesuai dengan tujuan yang orang tua harapkan.Pendidikan dimulai dari anak sebelum lahir dari kandungan ibu .lbu adalah orang tua dari anak itu sendiri,Jadi orang tua sejak dini telah mendidik anak agar sikap dan perilakunya anak tersebut sesuai dengan apa yang diharapkan ,baik orang tua ,masyarakat bangsa serta agama.

Sikap dan tingkah laku merupakan wujud dari sikap perilaku dalam diri seseorang yang tentunya adalah bukti dari sikap perilaku yang ditunjukkan dalam gerak gerik serta sopan santun di setiap saat mencerminkan orang lain.Sesorang dapat dikatakan memiliki nilai moral yang kita inginkan apabila seseorang tersebut benar-benar berperilaku disiplin diri dan mampu mengendalikan diri dan nilai sikap perilaku dapat dinilai dari dua sisi yang baik dan buruk sesuai didikan orang tua dirumah.

Dalam pasal I Undang-vndang Perkawinan Nomor I Tahun 1974 dikatakan bahwa "Perkawinan adalah ikatan lahir dan batin antara seorang pria dan seorang wanita sebagai suami isteri dengan tujuan membentuk keluarga yang bahagia dan sejahtera berdasarkan Ketuhanan Yang Maha Esa. Anak yang lahir dari perkawinan ini adalah anak yang sah dan menjadi hak dan tanggung jawab kedua orang tua untuk memelihara dan mendidiknya dengan sebaik-baiknya. Kewajiban orang tua mendidik anak ini terus serlanjutnya sampai ia dikawinkan atau dapat serdiri sendiri".

Zakiah Daradjat mengatakan bahwa orang tua merupakan pendidik utama dan pertama bagi anak-anak mereka, karena dari merekalah anak mula-mula menerima pendidikan. Dengan demikian bentuk pertama dari pendidikan terdapat dalam kehidvpan keluarga.

Dari dua dasar pemikiran di atas terlihat betapa besarnya tanggung jawab orang tua terhadap anak. Secara lebih tegas Allah SAW menjelaskan tentang kewajiban mendidik anak ini dalam surat At-Tahrim ayat 6 yang artinya: wahai orangorang yang beriman peliharalah dirimu dan keluargamu dari api neraka. (Q. S. AtTahrim ayat 6).

Ayat tersebut megandung makna "perintah" atau fi'il amar yaitu suatu kewajiban yang harus ditunaikan oleh kedua orang tua terhadap anaknya. Oleh karena itu, maka kedua orang tua harus dapat memainkan peranan penting sebagai pendidikan pertama dan utama bagi anaknya, sebelum pendidikan anak diserahkan kepada orang lain.

Menvrut Fuad Ihsan, tanggung jawab pendidikan oleh kedua orang tua meliputi:

a. Memelihara dan membesarkannya. Tnggung jawab ini merupakan dorongan alami untuk dilaksanakan, karena anak memerlukan makan, minum dan perawatan, agar ia dapat hidup secara berkelanjutan.

C. Melindvngi dan menjamin kesehatannya, Baik secara jasmani maupun rohani dari berbagai gangguan penyakit atau bahaya lingkungan yang dapat membahayakan dirinya.

Mendidiknya dengan berbagai ilmu pengetahuan dan keterampilan yang bergvna bagi hidupnya, sehingga apabila ia dewasa ia mampu berdiri sendiri dan membantu orang lain serta melaksanakan fungsi kekhalifahannya.

Membahagiakan anak untuk dunia dan akhirat dengan memberinya pendidikan agama sesuai dengan tuntunan Allah sebagai tujuan akhir hidup muslim. Tanggung jawab ini dikategorikan juga sebagai tanggung jawab kepada Allah.

Pendidikan merupakan hal terbesar yang selalu diutamakan oleh para orang tua. Saat ini masyarakat semakin menyadari pentingnya memberikan pendidikan yang terbaik kepada anak-anak mereka sejak dini. Untuk itu orang tua memegang peranan yang sangat penting dalam membimbing dan mendampingi anak dalam kehidupan sehari-hari. Sudah merupakan kewajiban para orang tua untuk menciptakan 
lingkungan yang kondusif sehingga memancing potensi anak, kecerdasan dan rasa percaya diri. Dan tidak lupa memahami tahap perkembangan anak serta kebutuhan pengembangan potensi kecerdasan dari setiap tahap.

Ada banyak cara untuk memberikan pendidikan kepada anak baik formal maupun non formal. Adapun pendidikan formal tidak sebatas dengan memberikan pengetahuan dan keahlian kepada anak-anak mereka di sekolah. Selain itu pendidikan non formal menanamkan tata nilai yang serba luhur atau akhlak mulia, norma-norma, cita-cita, tingkah laku, dan aspirasi dengan bimbingan orang tua di rumah.

Sekolah sebagai salah satu sarana pendidikan formal memerlukan banyak hal yang mendukung yaitu antara lain kepentingan dan kualitas yang baik dari kepala sekolah dan guru, peran aktif dinas pendidikan atau pengawas sekolah, peran aktif orang tua dan peran aktif masyarakat sekitar sekolah. Pendidikan anak dimulai dari pendidikan orang tua di rumah dan orang tua yang mempunyai tanggung jawab utama terhadap masa depan anak-anak mereka, sekolah hanya merupakan lembaga yang membantu proses tersebut. Sehingga peran aktif dari orang tua sangat diperlukan bagi keberhasilan anak-anak di sekolah supaya anak mampu mengenali dirinya (kekuatan dan kelemahannya), anak dapat mengembangkan potensi sesuai bakat dan minatnya, bisa meletakkan pondasi yang kokoh untuk keberhasilan dan membantu anak merancang hidupnya.

Karena begitu penting peran orang tua, tidak jarang mereka memaksakan kehendak mereka terhadap anak-anak mereka tanpa mengindahkan pikiran dan suara hati anak. Orang tua merasa paling tahu apa yang terbaik untuk anak-anak mereka. $\mathrm{Hal}$ ini sering dilakukan oleh orang tua yang berusaha mewujudkan impian mereka, yang tidak dapat mereka raih saat mereka masih muda, melalui anak mereka.

Pada dasarnya setiap orang tua menghendaki anaknya baik. Setiap orang tua mengharapkan anaknya patuh. Setiap orang tua akan merasa bahagia jika anaknya pintar. Dan, banyak lagi harapan lain tentang anak, yang kesemuanya berbentuk sesuatu yang positif.

Sementara itu, setiap orang tua berkeinginan untuk mendidik anaknya secara dan berhasil. Mereka berharap mampu membentu anak yang punya kepribadian. Anak yang beriman dan bertakwa kepada Tuhan Yang Maha Esa. Anak yang berakhlak mulia. Anak yang berbakti terhadap orang tua. Anak yang berguna bagi dirinya, keluarga, masyarakat, nusa, bangsa, negara, juga bagi agamanya. Anak yang cerdas dan terampil.

Namun, apa hendak dikata. Terkadang harapan tinggal harapan semata. Mimpi tak jadi kenyataan. Bagai pungguk merindukan bulan. Kenyataan yang amat bertentangan dengan harapan, malah itu yang harus dihadapi. Harus diterima. Ini pahit sekali. Getir sekali. Apakah itu seudah menjadi suratan takdir?

Akhir dari segala urusan kembali kepada Tuhan. Akan tetapi, manusia sebagai hamba-Nya diwajibkan berusaha dengan segenap daya tanpa berputus asa. Termasuk dalam hal mendidik anak, agar apa yang menjadi harapan Insya Allah akan dapat dirasakan.

Mencermati beberapa uraian di atas, timbul sebuah pemikiran mengenai beberapa hal yang menyangkut perbuatan mendidik, peran dan tanggung jawab orang tua guna dapat mendidik anak-anaknya, demi terwujudnya harapan membentuk generasi penerus bangsa yang berkualitas secara utuh, yaitu memiliki iman dan taqwa, etika, rasa tanggung jawab. 


\section{METODE}

Dalam memecahkan suatu masalah agar dapat diselesaikan secara baik, maka diperlukan data yang valid. Untuk mendapatkan data tersebut maka diperlukan suatu teknik pengumpulan data. Dalam penulisan ini teknik pengumpulan data ditempuh dengan studi pustaka.

Dalam usaha mengmpumpulkan data penulisan melalui teknik studi pustaka, dilakukan pencatatan buku, majalah, dan surat kabar yang terkait dengan tema penulisan, sehingga data yang dibutuhkan dapat terkumpul. Data tersebut diperoleh di perpustakaan, untuk mempermudah mencari data di perpustakaan digunakan media catalog yang ada. Selain di perpustakaan penulis juga mencari data melalui internet cara yang ditempuh penulis dalam mengumpulkan data dengan cara datang ke warnet (warung internet), untuk mengakses data yang berkaitan dengan masalah yang sedang diteliti.

Studi pustaka merupakan sebuah penelitian di perpustakaan yang bertujuan mengumpulkan data dengan bantuan bermacam-macam materi yang terdapat di ruang perpustakaan, misalnya: buku, surat kabar, majalah, dokumen, dll. Data tersebut berfungsi sebagai wahana informasi terhadap materi yang akan dibahas dalam penelitian.

Dalam karya tulis ini diolah dengan cara menyajikan dan menganalisis data kemudian diambil kesimpulan. Dalam hal ini, data dari buku tentang pendidikan anak serta pengaruh orang tua di dalamnya. Setelah itu, data-data yang dapat digunakan dari internet yang berkenaan dengan masalah yang sedang ditulis mengenai peran orang tua terhadap pendidikan anak, dianalisis berdasarkan teori-teori yang ada, kemudian ditarik suatu kesimpulan.

Analisis data adalah proses pengorganisasian dan pengurutan data dalam pola, kategori, dan uraian dasar sehingga akan dapat diteukan tema dan dapat dirumuskan hipotesis kerja seperti yang disarankanh oleh data (Lexy J. Moleong, 1993). Analisis data dalam karya tulis ini dilakukan dengan cara menguji, menyesuaikan, dan mengkategorikan data dengan teori yang ada dalam telaah pustaka.

\section{HASIL DAN PEMBAHASAN}

Anak adalah titipan Tuhan Yang Maha Kuasa, karena itu nasib dan masa depan anak-anak adalah tanggung jawab kita semua. Tetapi tanggung jawab utama terletak pada orang tua masing-masing (Riski, 2007:4). Orang tualah yang pertama berkewajiban memelihara, mendidik, dan membesarkan anak-anaknya agar menjadi manusia yang berkemampuan dan berguna. Setelah seorang anak kepribadiannya terbentuk, peran orang tua selanjutnya adalah mengajarkan nilai-nilai pendidikan kepada anak-anaknya. Pendidikan yang diberikan oleh orang tua kepada anaknya adalah merupakan pendidikan yang akan selalu berjalan seiring dengan pembentukan kepribadian anak tersebut. Peran orang tua terbatas pada persoalan dana. Salehlapadi dalam Emaniar mengemukakan bahwa orang tua dan masyarakat belum terlibat dalam proses pendidikan menyangkut pengambilan keputusan monitoring, pengawasan dan akuntabilitas. Akibatnya sekolah tidak mempunyai beban untuk mempertanggungjawabkan hasil pelaksanaan pendidikan kepada orang tua.

Anak merupakan masa depan bagi setiap orang tua. Pada usia balita, anak-anak yang kurang mendapat kasih sayang dan perhatian orang tuanya seringkali pemurung, labil dan tidak percaya diri. Ketika menjelang usia remaja kadang-kadang mereka mengambil jalan pintas, dan minggat dari rumah dan menjadi anak jalanan. Kesibukkan orang tua yang berlebihan, terutama ibu, menyebabkan anak kehilangan perhatian. Seorang ibu yang berkarir di luar rumah misalnya dan karirnya banyak menghabiskan waktu, lebih banyak menghadapi masalah kekurangan interaksi ini. Bisa dibayangkan, bila dalam sehari ibu hanya punya waktu paling banyak $2-3$ jam 
bertemu dengan anak. Anak lebih dekat dengan pengasuh atau pembantunya. Pada faktanya televisi tidak mampu menjadi orang tua yang baik, karena acara-acara yang ditayangkan tidak semuanya baik. Masih ada film anak-anak yang kurang mendidik dan terkesan merangsang anak melakukan tindakan perlawanan yang diputar di stasiun televisi di Indonesia. televisi tidak begitu baik untuk masa depan pendidikan anak-anak masa kini. Karena masa depan anak itu dilihat dari pendidikan yang diberikan orang tua sejak dini.

Dengan memberikan pendidikan yang setinggi-tingginya, semua hidup anakanak akan berjalan mulus, pendidikan anaklah dasar kehidupan. Dan juga pendidikan masih merupakan investasi yang mahal. Peran orang tua dalam pendidikan mempunyai peranan besar terhadap masa depan anak. Sehingga demi mendapatkan pendidikan yang terbaik, maka sebagai orang tua harus berusaha untuk dapat menyekolahkan anak sampai ke jenjang pendidikan yang paling tinggi adalah salah satu cara agar anak mampu mandiri secara finansial nantinya. Sebagai orang tua harus sedini mungkin merencanakan masa depan anak-anak agar mereka tidak merana. Masa anak-anak merupakan masa transisi dan kelanjutan dalam menuju tingkat kematangan sebagai persiapan untuk mencapai keremajaan. Ini berarti kemajuan perkembangan yang dicapai dalam masa anak-anak merupakan bekal keberhasilan orang tua dalam mendidiknya. Baik buruknya sikap dan tingkah laku seseorang di masa anak-anak, sangat banyak ditentukan oleh pengalaman mereka dalam melihat orang-orang disekitarnya terutama kedua orang tuanya. Itu semua merupakan bekal pendidikan bagi anak-anak nantinya.

Di sisi lain, anak-anak adalah generasi yang memiliki sejumlah potensi yang patut dikembangkan dalam kegiatan pendidikan serta kreativitas mereka. Anak-anak mempunyai karakteristik antara lain pertumbuhan fisik yang cepat dan matang. Semua potensi anak tersebut akan bermakna apabila dibina dan dikembangkan secara terarah sehingga mereka menjadi manusia yang memiliki keberdayaan. Tanpa bimbingan yang baik semua potensi itu tidak akan memberikan dampak positif, bahkan bisa terjadi hal yang sebaliknya yaitu menimbulkan berbagai masalah dan hambatan. Apalagi jika melihat ke depan, tantangan globalisasi makin besar, maka pembinaan pendidikan terhadap anak pun harus semakin dikuatkan. Anak-anak harus berorientasi terhadap pandangan hidup yang bersifat positif dan aktif serta wajib menentukan dirinya sendiri, mementingkan kepuasan dari pekerjaan yang dilakukannya, berorientasi ke masa depan dan belajar merencanakan hidup secermat mungkin. Pendidikan merupakan sesuatu yang perlu mendapatkan prioritas.

Dalam sebuah keluarga, tentunya yang sangat berperan adalah ayah dan ibu (orang tua) dalam mendidik anak. Apa saja yang harus dilakukan oleh ayah dan ibu sebagai sebuah keluarga yang ideal dalam mendidik dan mengembangkan potensi/kemampuan anak-anak .

\section{SIMPULAN}

Orang tualah yang pertama berkewajiban memelihara, mendidik, dan membesarkan anak-anaknya agar menjadi manusia yang berkemampuan dan berguna. Setelah seorang anak kepribadiannya terbentuk, peran orang tua selanjutnya adalah mengajarkan nilai-nilai pendidikan kepada anak-anaknya. Pendidikan yang diberikan oleh orang tua kepada anaknya adalah merupakan pendidikan yang akan selalu berjalan seiring dengan pembentukan kepribadian anak tersebut.

Pendidikan anak merupakan tanggung jawab penuh dari kedua orang tua, bukan yang lain. Tanggung jawab bukan sebatas memilihkan sekolah atau membiayai sekolah dan segala keperluanya. Lebih dari itu, tanggung jawab orang tua diwujudkan dalam keterlibatan langsung orang tua dalam pendidikan (kehidupan) anak-anaknya. Ketika orang tua terlibat langsung dalam kehidupan dan pendidikan anak-anaknya, maka mereka akan memberi perlakuan yang lebih tepat kepada anak-anak. 
Keterlibatan orang tua dalam pendidikan anak berhubungan dengan prestasi anak, perilaku anak, budaya, usia, dan kualitas sekolah anak.

Kepada para orang tua hendaknya mengambil sikap yang bijak dan menjadi teladan bagi anak-anak mereka terutama dalam hal pendidikan. Orang tua sebaiknya tidak memaksakan kehendaknya atau untuk merealisasikan cita-cita orang tua yang belum tercapai. Kepada mahasiswa terutama jurusan keguruan serta dosen, tulisan ini sebagai bahan renungan dalam menjalankan pengajaran supaya dapat memperdalam pengetahuan dan keterampilan tentang cara-cara mengajar yang dapat membentuk kepribadian anak didik yang baik.

DAFTAR PUSTAKA

Daradjat, Zakiah. (1973). Peranan Agama dalam Kesehatan Mental. Jakarta: Gunung Agung.

Devi, S. (2007). Jadilah Pembimbing dan Guru bagi Putra Putri Anda. Bandung: NUANSA.

Ihsan, Fuad. (1997). Dasar-dasar Kependidikan. Jakarta: Rineke cipta

Kurniawan, Irwan Nuryana. (2008). "Orangtua Terlibat dalam Pendidikan Anak". http://kurniawan.staff.uii.ac. (diakses 10 Oktober 2008 pukul 06.05)

Mansur, Yakhsyallah. (2007). "Tanggung Jawab Orang Tua dalam Pendidikan Anak".http://kajianmuslim.wordpress.com. (diakses 9 Oktober 2008 pukul 20.38).

Nasution, S.(1982). Berbagai Pendekatan dalam Proses Belajar Mengajar. Bandung: PT Bumi Aksara.

Rahayu, Puji. (2008). "Orang Tua Perlu Pahami Makna Pendidikan Anak “. http://bbawor.blogspot.com/2008/08/orang-tua-perlu-pahami-maknapendidikan.html. (diakses 10 Oktober 2008 pukul 05.56)

RI. (1997). Undang-Undang Peradilan Anak (UU No. 3 Tahun 1997). Jakarta: Sinar Grafika.

Suwarno. (1982). Pengantar Umum Pendidikan. Jakarta: Aksara Baru.

Syafei, Sahlan.(2002). Bagaimana Anda Mendidik Anak. Depok: Ghalia Indonesia. 